\title{
THE HWAJOHWA GENRE (BIRD-AND-FLOWER PAINTING) IN KOREAN TRADITIONAL PAINTING OF THE LATE CHOSŎN PERIOD (18th - EARLY 20th CENTURIES)
}

Summary: This article is devoted to the hwajohwa artistic genre (bird-and-flower painting) of the late Chosŏn period ( $18^{\text {th }}$ - early $20^{\text {th }}$ centuries). The study identifies the historical and cultural context and traces the stylistic evolution of the bird-andflower genre. The national features inherent in Korean hwajohwa painting, as well as the influence of traditional Chinese styles and Western European painting techniques on the bird-and-flower genre, are noted. The author outlines the leading artists working in this genre.

In the $18^{\text {th }}$ century, the bird-and-flower painting in Korea underwent a significant transformation. The work of professional artists Chŏng Sŏn and Pyŏn Sangbyŏk presents a new realistic approach to hwajohwa painting. Artists began to carefully observe the structural characteristics of the depicted objects of wildlife. Also, artist Sim Sajŏng was a recognised master of the bird-and-flower genre. His work was based on the Chinese "southern school" pictorial principles and aesthetics, the influence of which was strong in Korea.

Kim Hondo, the leading artist of the late Chosŏn period, actively used traditional landscape as a background for his works with flowers and birds. However, in depicting living creatures, he did not use formal templates, painting birds in realistic nature scenes. Kim Hondo contributed significantly to the devel- opment of Korean traditional painting and the hwajohwa genre.

The popularity of the bird-and-flower genre in the late Chosonn period is mainly due to economic growth and the improvement in the welfare of ordinary people. Most of the works of this genre were created by artists from the people. The works were examples of the so-called minhwa folk painting, which developed in accordance with the requests of a new customer, a native of the lower and middle classes. Such works combined auspicious symbols and were the embodiment of the highest harmony of nature. However, they also began to be used simply to decorate the house.

In the hwajohwa painting of the $19^{\text {th }}$ century, a new approach to the depiction of an artist's personal experiences was reflected; such trends were mixed with the traditional "painting of ideas". The birdand-flower genre acquired a free style and conveyed fresh aesthetic feelings under the influence of the work of artist Chang Sŭngŏp, whose pictorial approaches were continued and developed by masters at the very end of the Chosonn era.

Keywords: Korean traditional painting of the Chosŏn period, the hwajohwa genre (bird-andflower painting), Chŏng Sŏn, Cho Yŏngsŏk, Pyŏn Sangbyŏk, Sim Sajŏng, Kim Hondo, Hong Sesŏp, Chang Sŭngŏp, Cho Sŏkchin, An Junsik. 


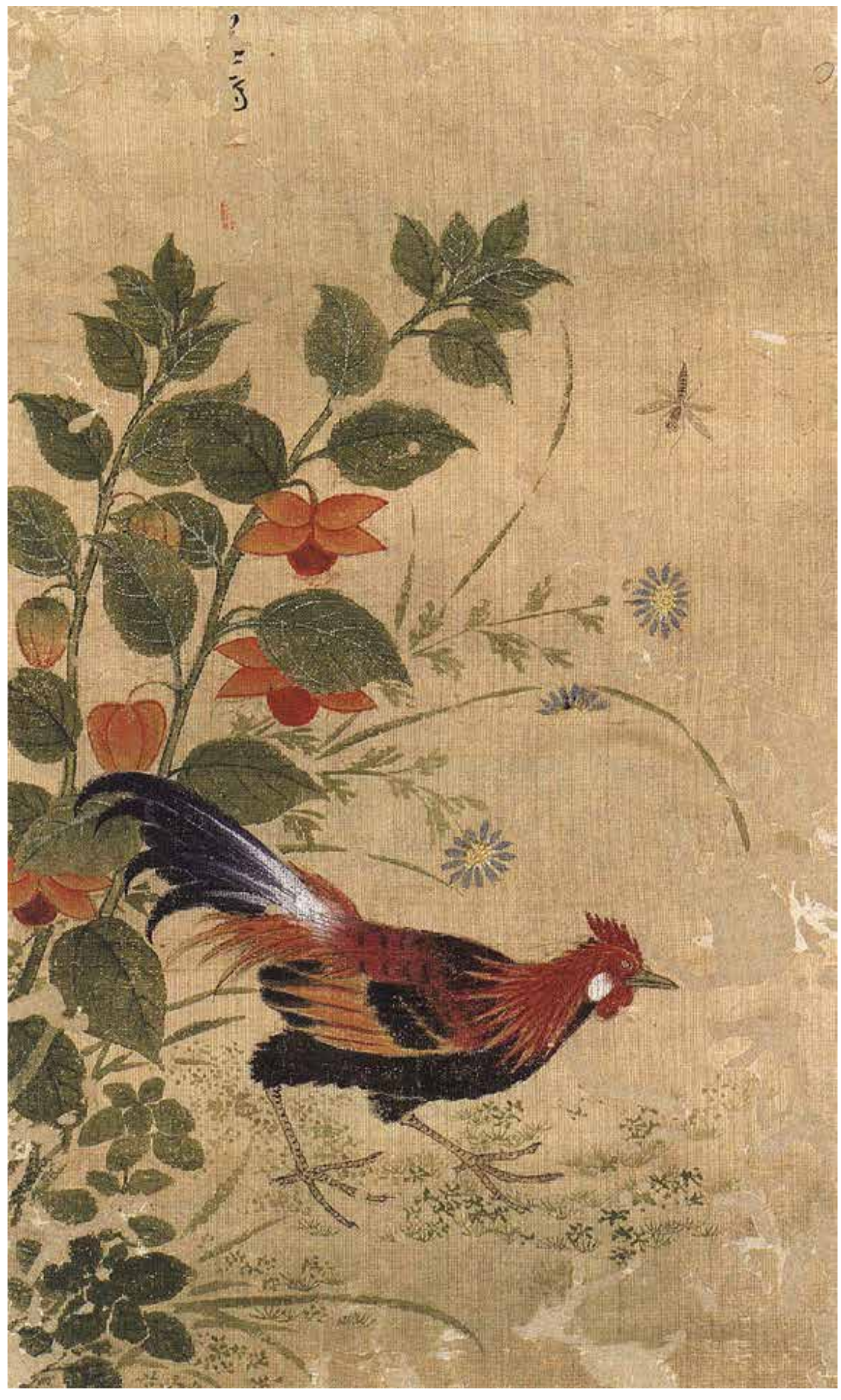

(Fig. 1) Chöng Sŏn, Physalis and the Rooster, silk, ink, watercolours, ch'aesaek technique (채색 彩色, colouring the depicted object after
drawing its outline), $30.5 \times 20.8 \mathrm{~cm}$, first half of the $18^{\mathrm{m}}$ century, Kansong Art Museum, Seoul
The Chosŏn era (reign of the Yi Dynasty, 13921910 ) is a period of five hundred years in Korean history. This article is a continuation of the study $[1$, pp.72-78] of the bird-and-flower genre in Korean traditional painting and describes the processes that took place in the designated art movement in Korea in the $18^{\text {th }}$ - early $20^{\text {th }}$ centuries. In modern South Korean art history, this period of history is usually called the late Chosonn period. It is subdivided into two stages: the late Chosŏn period, conventionally dated 1700-1800, and the end of the Chosŏn era, conventionally dated 1800-1910. (Note that some Korean researchers date the end of the Chosonn period from 1850 to 1910). The author uses the terms hwajohwa (화조화 花鳥畫) to denote the bird-and-flower genre and hwajodo (화조도 花 鳥圖) to denote paintings made in this genre [for more details on terminological features, see 1, p.73].

Hwajohwa in the Late Chosonn Period

\section{(c. 1700-1800)}

In the history of the Chosonn period, the $18^{\text {th }}$ century is considered one of the most stable and prosperous. There were no wars or foreign invasions on the Korean Peninsula; trade and crafts were active$y$ developing; the middle class of low-ranking officials, merchants and artisans gradually grew rich. With the coming to power of the Manchu dynas-

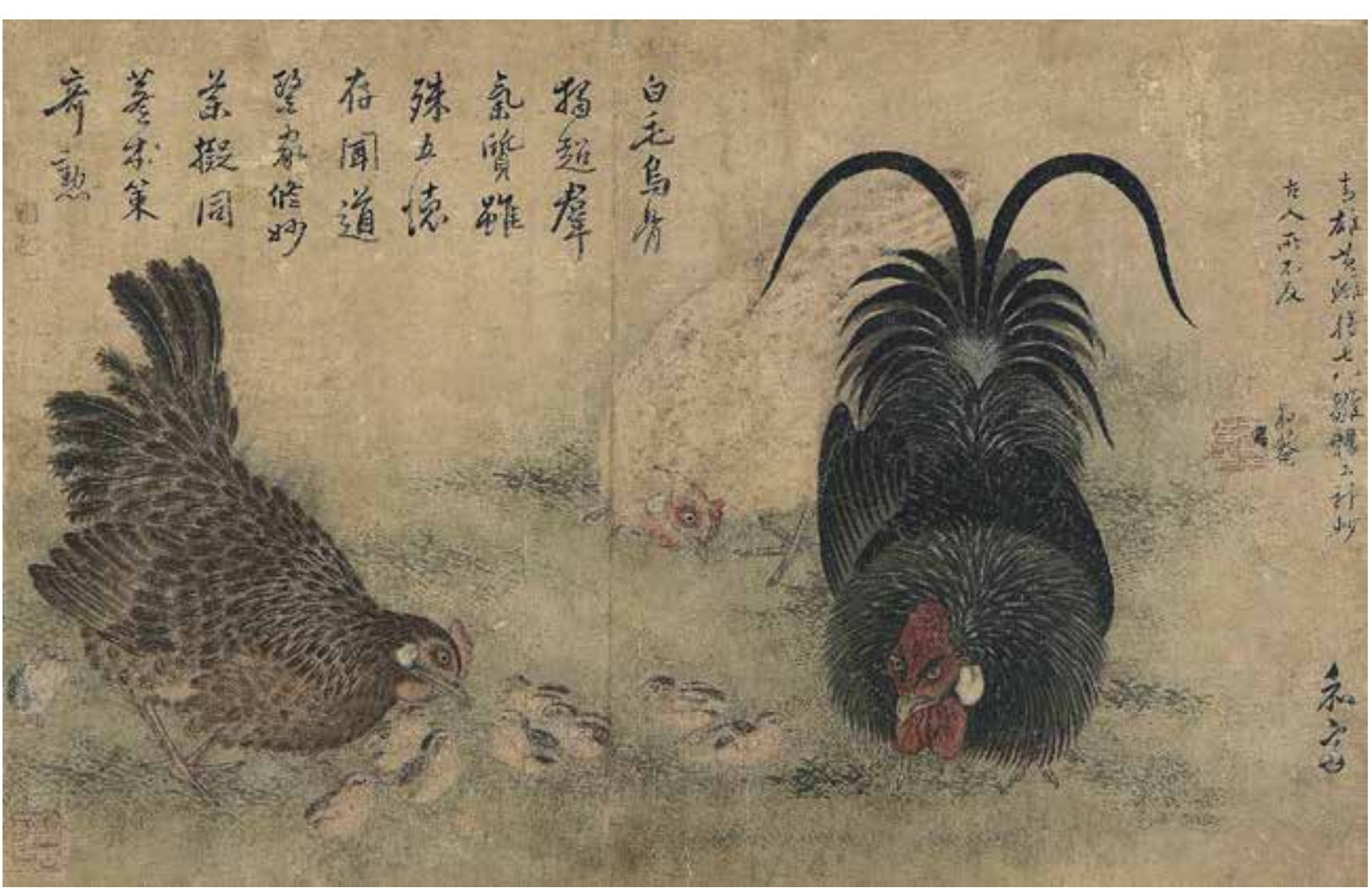
(Fig. 2) Pyŏn Sangbyök, Rooster and Chickens Guarding Chicks, paper, ink, watercolours, ch'aesaek technique, $30 \times 46 \mathrm{~cm}$, mid-18 $18^{\text {th }}$
century, Kansong Art Museum, Seoul ty in China (1644-1912), which Koreans considered "barbaric", Chosŏn, in the eyes of its intelligentsia began to be perceived as a new centre, the heart of neo-Confucian culture. Despite the continued influence of China, a search for self-identification began in Korean academic circles, accompanied by an rectly reflected in art and painting. selves in the noticeable development of the "true view" landscape movements, chingyŏng sansuh$w a$ (진경산수화 題景山水畫) and p'ungsokhwa (풍 속화 風俗畫) everyday genre painting. However the hwajohwa genre also underwent a significant transformation. This process was associated with the emergence of new artistic trends and the strengthening of the influence of the Chinese «southern school», or the namjonghwa painting (남종화 南宗畫, Chinese: nanzonghua), in Korea.

Monochrome ink painting, which gravitated towards calligraphy and convention and which was little understood by common people, began to be less popular. Painting with ink and water paints ch'aemukp'ung (채묵풍 彩墨風), detailed elaboration of paintings, rich colour popular at the very beginning of the reign of the Yi dynasty (1392-1550) [1, pp. 74-75] became widespread again. In the middle strata of Korean soincrease in national self-awareness, which was di-

First of all, these tendencies manifested them- 
ciety, whose well-being had significantly improved by the $18^{\text {th }}$ century, the demand for a vivid depiction of nature increased. Moreover, the pictorial albums imported for copying from early Qing China started to consist of colour woodcuts, which also influenced Korean society's tastes and aesthetic needs.

One of the key places in the formation of the national painting of Korea is occupied by artist Chŏng Sŏn (정선 鄭缮, pseudonym: Kyŏmjae 겸재 謙齋, 1676-1759), who became famous primarily for his "true view" landscapes. He painted little in the birdand-flower genre; however, Korean art critics unanimously declare that Chŏng Sŏn had an unrivalled talent for conveying the essence of nature and living things. His works Physalis and a Rooster (등롱웅 계도 燈籠雄鷄圖) (Fig. 1) and Celosia and Late [Autumn?] Chickens (계관만추도 䊿冠晚雛圖) from the Kansong Art Museum have been preserved. In the paintings, the composition is traditional; we see the concentration of the main objects in one corner of small landscape. However, the image of birds and plants demonstrates a realistic approach to painting [5, pp.234-235]. In Physalis and a Rooster the combination of orange and red in the fruits of the

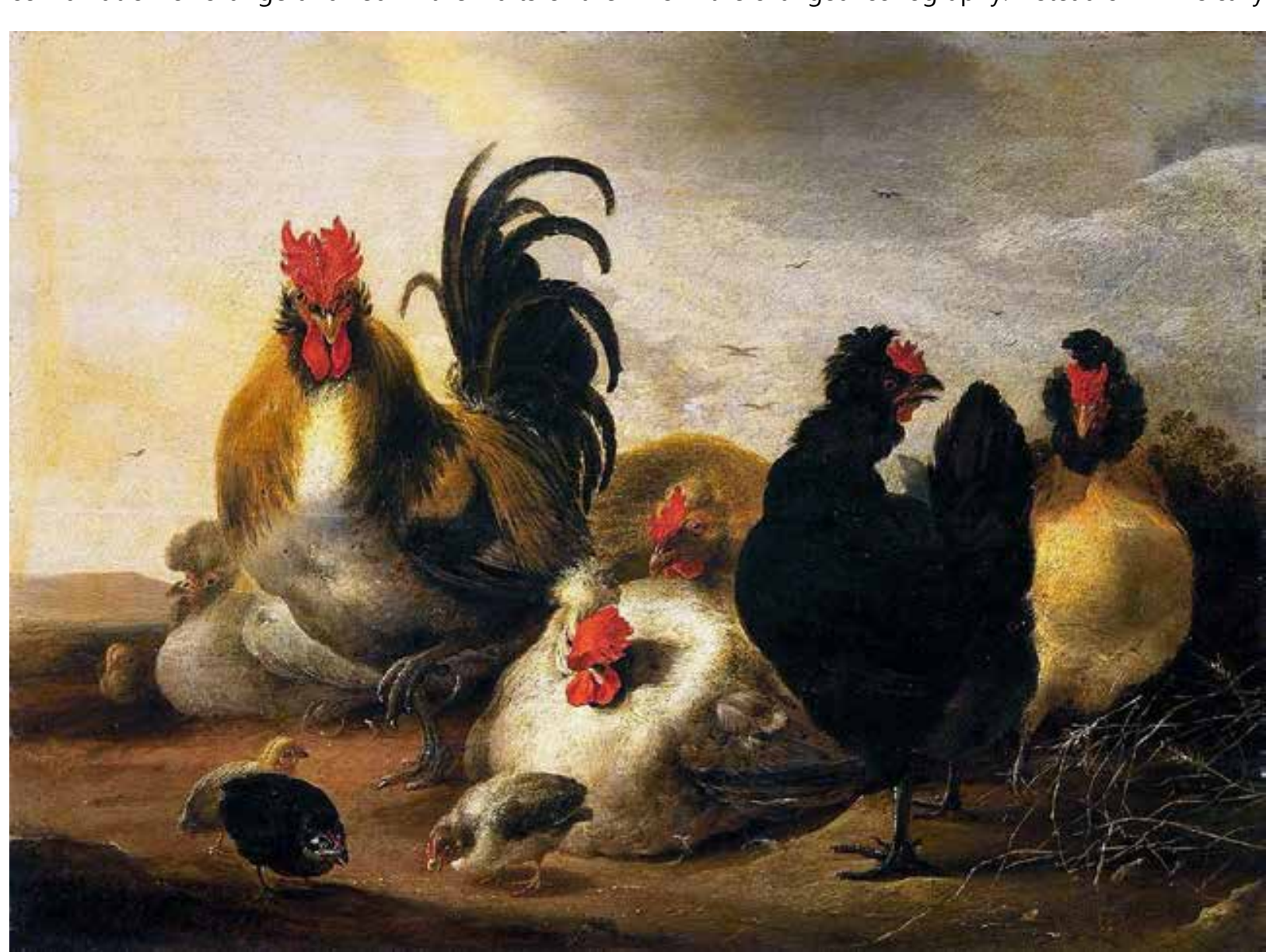

(Fig. 3) Geisbert Gillis d'Hondecoeter, Rooster and Chickens in a Landscape, oil on board, $55 \times 74 \mathrm{~cm}, 1651$ ?
Mauritshuis Royal Gallery, Hague (자득적 自得的), that is self-learning by observing the structural characteristics and the most mino features of the object under study. This movement in painting was developed by artist Cho Yŏngsŏk (조영석 趙榮祏, pseudonym: Kwanajae, Sǒkkyesanin 관아재 觀我齋, 석계산인 石溪山人, 1686-1761), who painted an object exactly as it was, or chŭngmul sajin (즉물사진 師物寫眞). He was a childhood friend and neighbour of great Chŏng Sŏn. In the first phase of his work, Cho Yŏngsŏk practised rough sketching with willow charcoal, yut'an yaksa (유탄약사 柳 炭略寫). Creating his famous painting Magpies on a Pine / A Pair of Magpies (송작도 松鹊圖 / 쌍작 도 雙鹊圖) from a private collection, Cho Yŏngsŏk worked with ink and white chalk hobun (호 본 basing on just such full-scale sketches... The fundamental difference between this work and the paintings of the middle Chosŏn period (c. 1550-1700) is in the changed iconography: instead of whimsically curved, as if broken, thin twigs of plum or bamboo, the painting has a powerful pine branch, which serves as reliable support for light, as if weightless birds.

Outstanding court painter Pyŏn Sangbyŏk (변상 벽 卡相璧, pseudonym: Hwajae 화재 和齊, 17301775?) became famous for his bright multicoloured works in the bird-and-flower genre. The artist re- ceived the nickname "Pyŏn-cat" for the magnificen drawings of cats and "Pyŏn-rooster" for painting roosters and hens. His painting Rooster and Chickens Guarding Chicks (자웅장추도 雌地哆够圖) from the Kansong Art Museum (Fig. 2) is considered one of the pinnacles of the hwajohwa genre in Korean traditional painting [7, pp.128-135; 8, p.109]. The

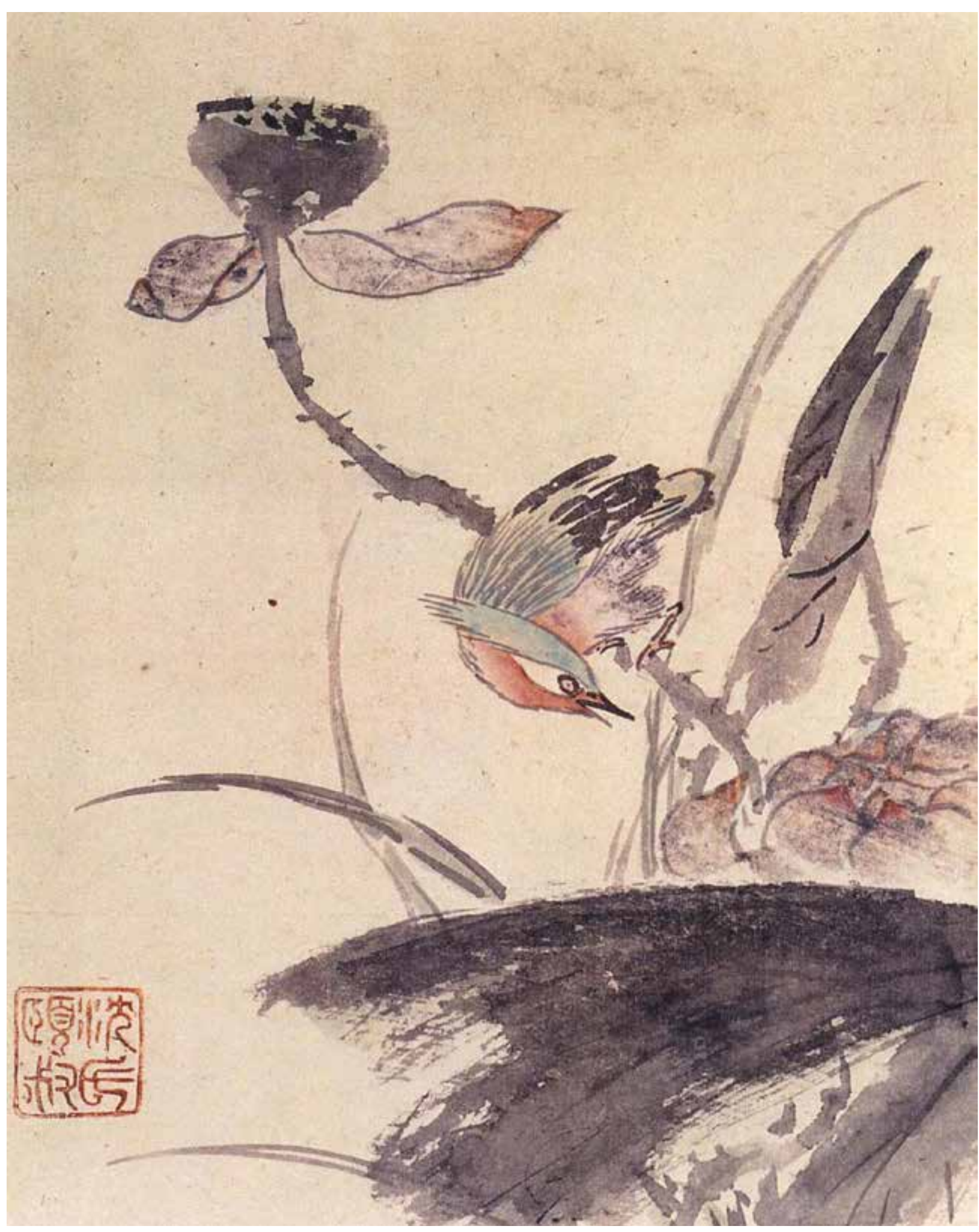
(Fig. 4) Sim Sajöng, Bird [Kingfisher] Smelling a Scent, paper, ink, watercolours, tamch'ae technique (담 채 淡彩, lightlly colouring the
depicted objects and the background with paints and ink), $27.2 \times 21.1 \mathrm{~cm}$, middle $18^{\text {th }}$ century, Kansong Art Museum, Seoul 


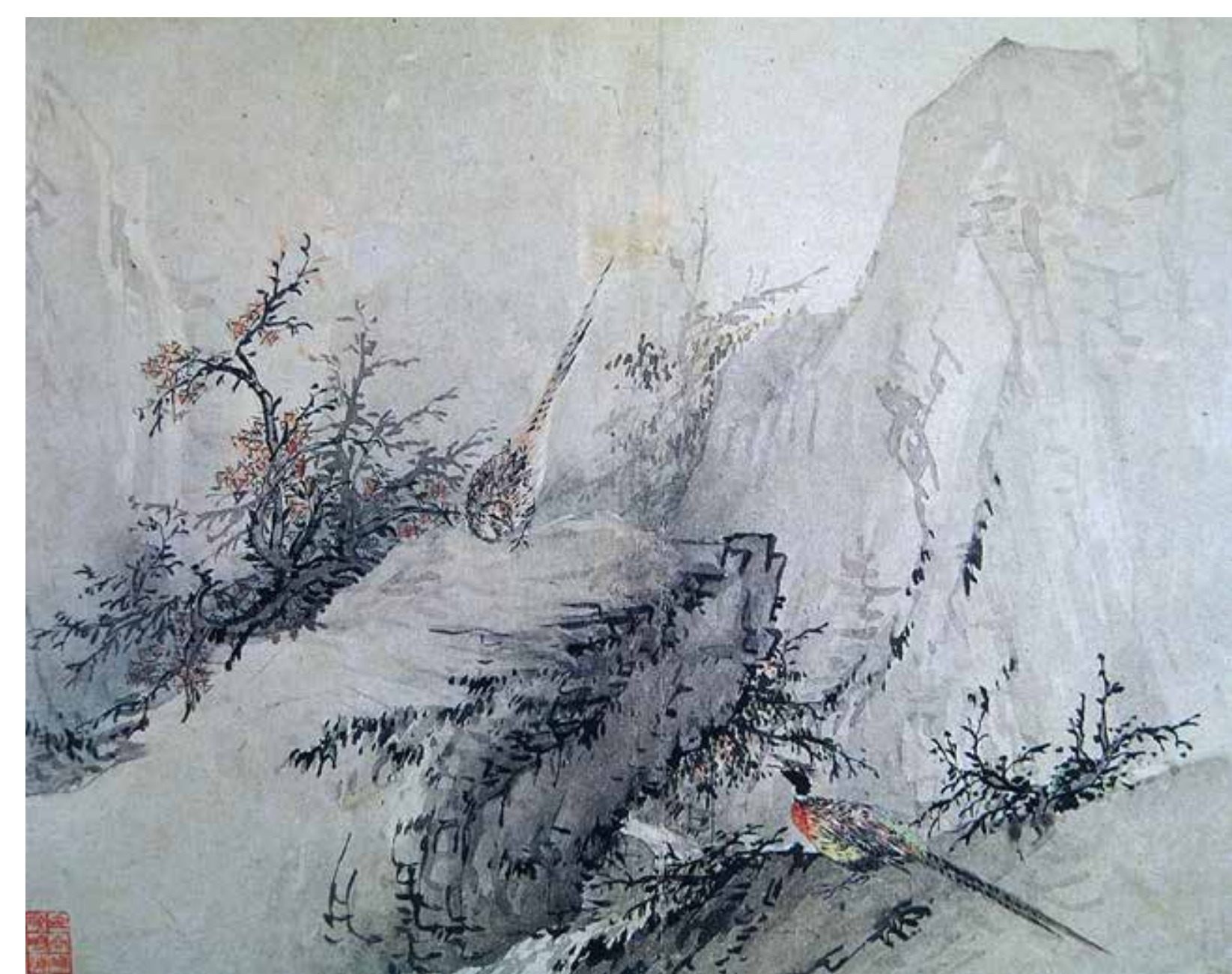

(Fig. 5) Kim Hondo, A Pair of Pheasants in the Autumn Forest, paper, ink, watercolours, tamch'ae technique, $26.7 \times 31.6 \mathrm{~cm}, 1796$
Leeum Museum, Seoul

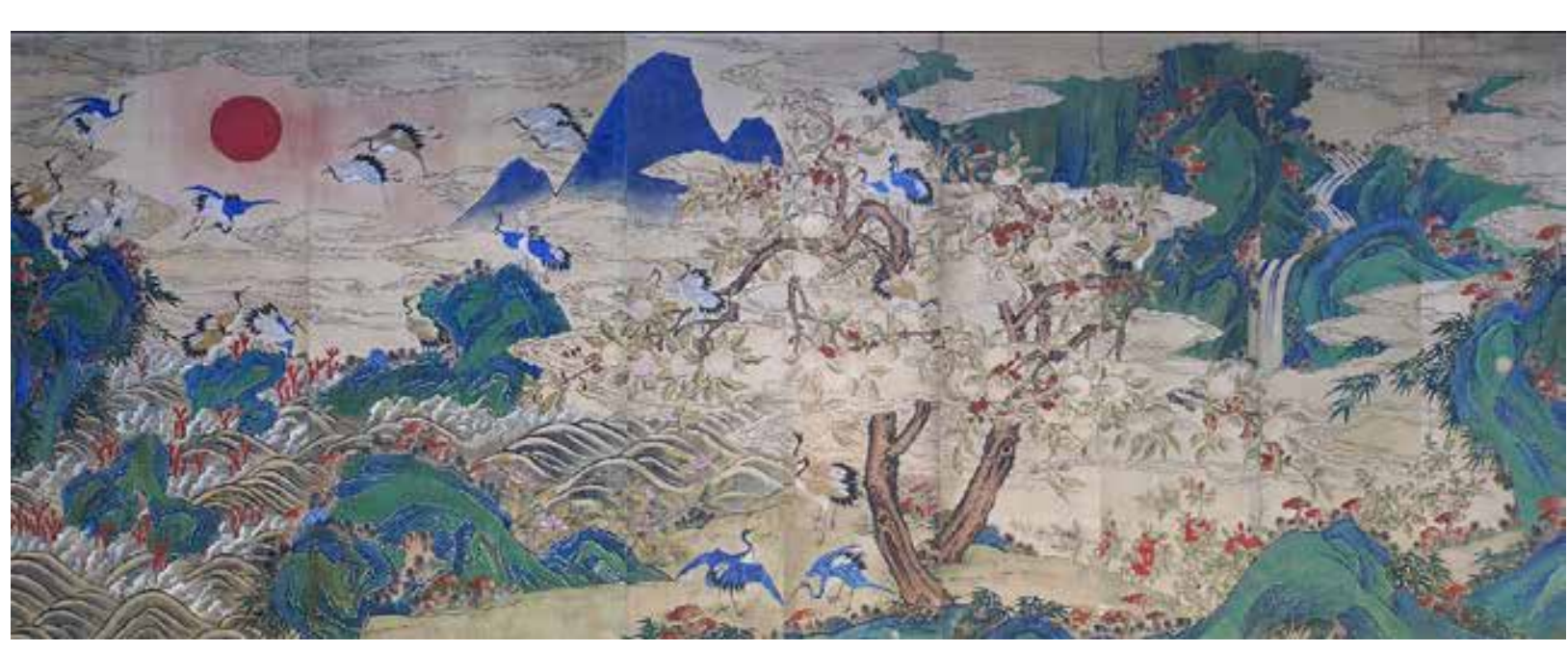

(Fig. 6) Unknown artist, ten-fold screen Spring in the Mountains (동산의 봄, 소산춘경색 小山春景色), silk, ink,

work is characterised by atypical realism. The contrast between the plumage of adult birds and the light fluff covering the chicks is conveyed perfectly. The stiff feathers of the rooster seem to glare reflecting the sunlight, while the chickens seem almost incorporeal.
The painting is characterised by an innovative composition: birds are presented in bold angles and turns that emphasise spatial depth. Such techniques were clearly borrowed from the arsenal of Western European art. It is worth noting that in the $18^{\text {th }}$ century, Western pictorial techniques were beginning to appear on the Korean Peninsula through Qing China although indirectly. Foreign artists worked at the courts of the Kāngxī (1661-1722) and Qiánlóng (1735-1796) emperors, who are considered the greatest patrons of art the most famous of whom was Jesuit monk Giuseppe Castiglione (1688-1768). In court academic painting, Chinese artists began to use linear and aerial perspectives and use chiaroscuro. Koreans, who regularly visited Beijing as part of diplomatic missions, certainly had the opportunity to get acquainted with new cultural trends brought to China by numerous Christian missionaries and trading companies. Gradually, Korean artists also began to apply the methods and techniques of European art.

In the $17^{\text {th }}-18^{\text {th }}$ centuries in Western European art, images of poultry yards (Fig. 3), bird concerts, chicken coops, and cockfights were becoming popular. Dutch artists Geisbert Gillis d'Hondecoete (1604-1653) and his son Melchior d'Hondecoete (1636-1695) were among the leading masters of this animalistic trend. The latter even received the nickname "Raphael of birds" by his contemporaries. During this period, a large number of objects of Western European art were imported into China and we cannot exclude that paintings with plots similar to those of Hondecoeter ended up on the Far Eastern market.

Of course, there is no conclusive evidence of Pyŏn Sangbyŏk's direct borrowing of the plot of The Rooster and Chickens Guarding Chicks; however, the likelihood of an indirect influence is very high. The circular composition of the arrangement of the figures of birds guarding their chicks, the placement of their bodies in space, the emphasised realism of the image - everything is new for Korean painting

Also, in the late Chosǒn period, a movement that used the sumuk tamch'aep'ung technique (수묵담 채풍 水墨淡彩風, ink painting with light colouring with mineral paints) was popular in the bird-andflower genre. It was based on the pictorial principles and aesthetics of the Chinese "southern school". The recognised master of this movement was Sim Sajŏng (심사정 沈師正 pseudonym: Hyŏnjae 현재 玄齊, 1707-1769), an artist with a difficult creative and human destiny, who lived a modest secluded life and died in poverty. However, he contributed significantly to the development of Korean traditional painting and was a renowned master of flowers, birds and insects.

While echoing the pictorial style of Qing artis Jiāng Tíngxī (蔣廷錫, 1669-1732), Sim Sajŏng some-

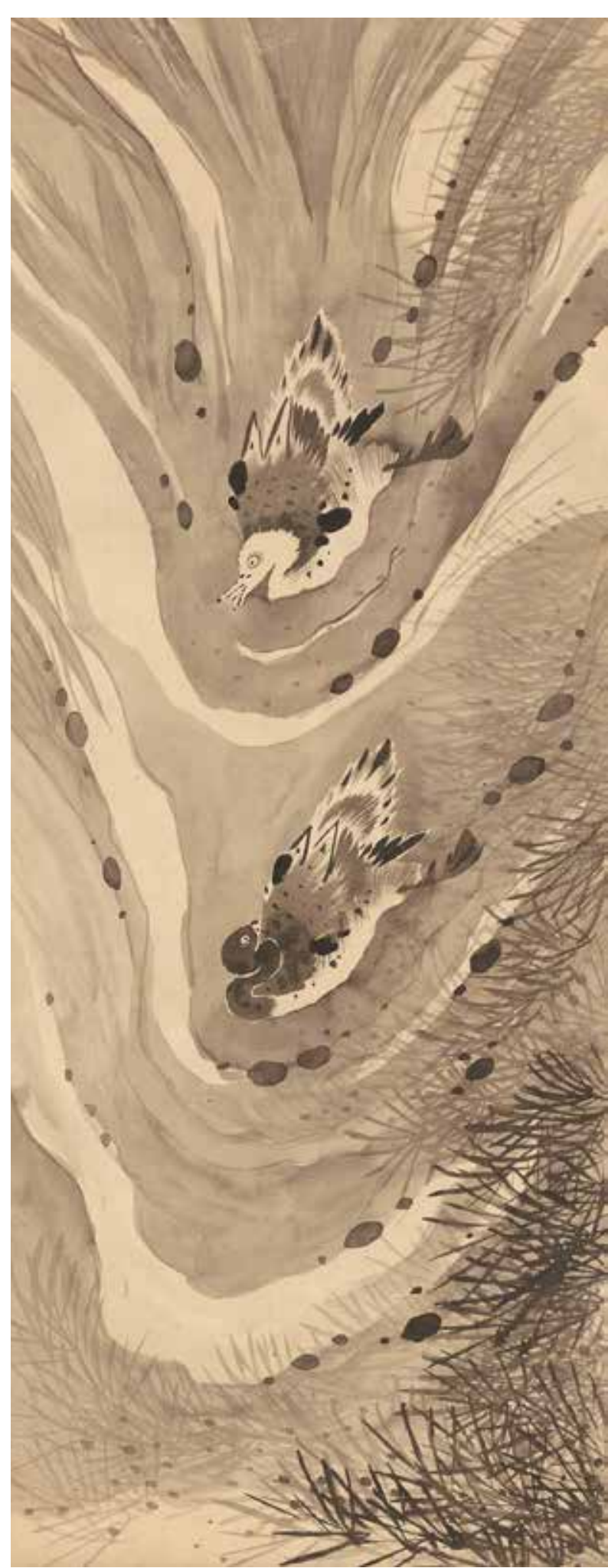

(Fig. 7) Hong Sesŏp, Swimming Ducks [in a Stream of Water]
silk, ink, sumuk technique (술 silk, ink, sumuk technique ( National Museum of Korea, Seoul

times used the flamboyant "careful brushing" technique of kongp'il ch'aesaekp'ung (공필채색풍 工筆 彩色風), that is accurate contouring of objects with great attention to detail and shape $[3$, p.57]. The artist's painting Ducks on a Lotus Pond (연지유압 


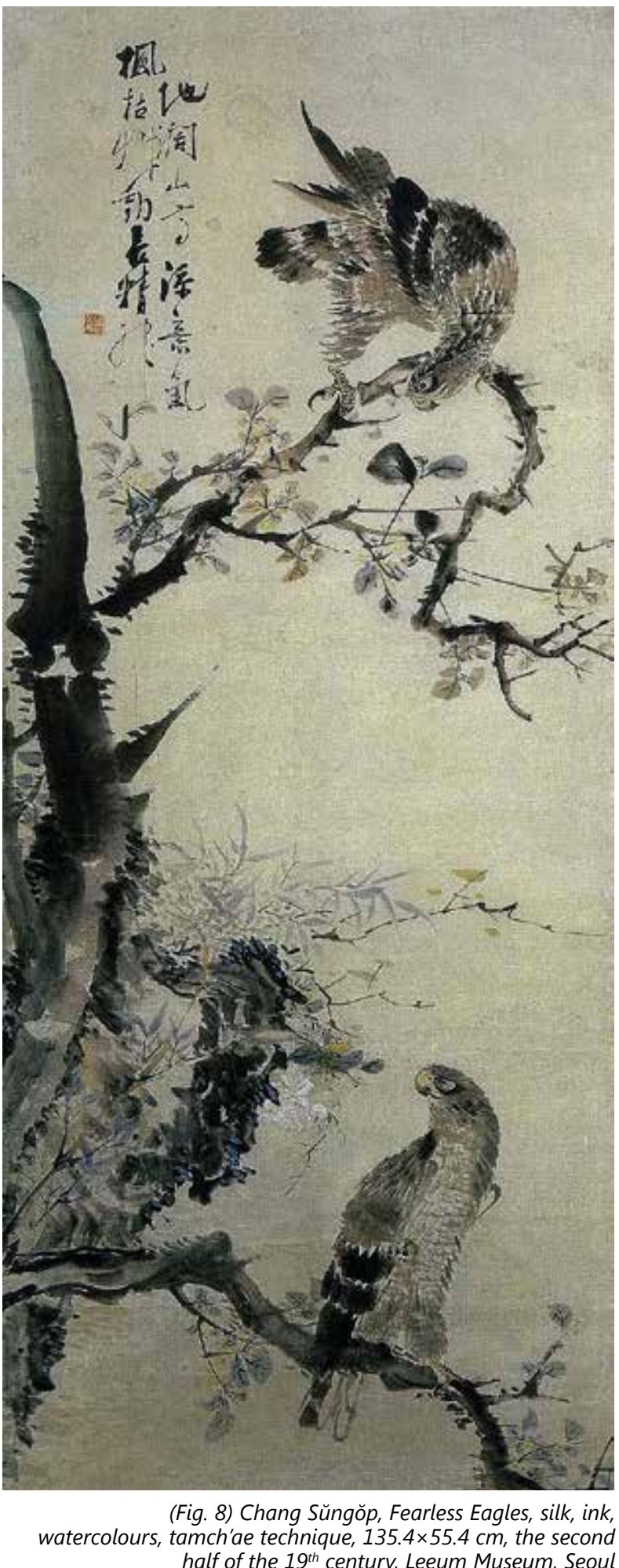

hamch'ae technique, $135.4 \times 55.4 \mathrm{~cm}$, the second

도 蓮池遊鴨圖) from the Leeum Museum perfectly demonstrates this painterly manner of the artist. At the same time, Sim Sajŏng used a variety of artistic techniques in his work. In part, he continued the tradition of Cho Sok (조속 趙涑, pseudonym Ch'anggang 창강 滄江, 1595-1668), an intellectual artist of the middle Chosŏn period [1, p.76], which can be seen in the free and powerful brushwork in Bird [Kingfisher] Smelling a Scent (수금문향 水禽
聞香) from the Kansong Museum (Fig. 4). Sim Sajŏng preferred to portray hawks, pheasants, woodpeckers and kingfishers. The artist was a great colourist his painting is recognisable and stands out amo the works of his contemporaries.

Sim Sajŏng's work was admired by representatives of the yŏhang (여항 䦓巷, the lower educated socia class formed from low-ranking officials in the late Chosŏn period), for example, the artists Ch'oe Buk (최북 崔北, pseudonym: Hosaenggwan, Samgijae 호 생관 毫生館, 삼기재 三奇齋, 1712-1786), who excellently painted hunting eagles, and Kim Hondo (김홍도 金弘道, pseudonym: Tanwŏn, Tangu, Sŏho 단원 檀園, 단구 丹邱, 서호 西湖, 1745-1806)

Kim Hondo is a genuinely significant figure in the cultural life of Korea. He was one of the best court painters of king Chŏngjo (정조 正祖, 1776-1800), had great talent, and his creative range was extensive [9]. Kim Hondo's artistic world was shaped by the works of Chŏng Sŏn and Sim Sajŏng.

The artist left behind many paintings with wild ducks, herons, magpies, pheasants, hawks and cranes. For his hwajodo, Kim Hondo used traditional smal and large landscapes as a background; however, in depicting living creatures, he moved away from typical and formal patterns, painting birds in realistic nature scenes with mountains, valleys, and rural fields. He actively used multi-figured compositions with a characteristic genre narrative and an entertaining plot. Ducks Floating on the River (계류유압도 溪流游鴨圖), A Pair of Pheasants in the Autumn Forest (추림쌍치도 秋林雙雉圖) (Fig. 5) and Magpies in Spring (춘작보희도 春鵲報喜圖) all of which are included in The Painting Album of the Pyŏngjin Year (병진년화첩 丙辰年畫帖) from the Leeum Museum, are the artist's best paintings with birds. Masterwork in bright, clear colour, composition balanced by empty space, distinguish Kim Hondo's style.

In the late Chosŏn period, a large number of paintings began to be painted in the blue-green colour of the ch'onngnokp'ung style (청록풍 青綠風) which used bright saturated colour in the image of birds, flowering trees, stones and rocks. The increased conventionality and decorativeness of paintings of this style made them one of the most popular item of decoration not only in palaces but also in the houses of the middle-class chungin (중인 中人), wealthy traders and merchants.

Brightly coloured screens with pines and cranes songhakto (송학도 松鶴圖) and haehakpandoryu
(해학반도류 海鶴憣桃類), images combining cranes and peach trees as symbols of longevity and immortality were popular among the decorative coloured hwajohwa. Palaces were often decorated with such screens; they demonstrated the wealth of the owner and the delicate work of the artist (Fig. 6).

Flowers and Birds (화조도 花鳥圖) by Sin Hanp'yŏng (신한평 申漢枰, pseudonym: Iljae 일 재 逸齋, 1726-?) from the Leeum Museum, Colourful Birds Among Blooming Trees (화림채금도 花林彩禽圖) by Yi Ǔiyang (이의양 李義養, pseudonym: Sinwŏn 신원 信園, 1768-? after 1824) from the Kansong Museum and the screens mentioned bove are united by a bright colour combination of green and red. In all these works, thin lines depict unusually beautiful stylised birds and plants.

The popularity of the hwajohwa genre in the $18^{\text {th }}$ century is primarily associated with economic growth and the improvement of the welfare of ordinary people. Paintings, timed to religious and shamanic rituals, various holidays, with wishes of longevity and a happy New Year, were made for all population strata. However, many works in the birdand-flower genre were intended simply to decorate the house, turning it into a fantastic paradise $[3$, p.59]. Interestingly, in the late Chosŏn period most of the paintings with flowers and birds were created by artists from the people; these were examples of the minhwa folk painting (민화 民畫). It is partly due to the fact that the period of the Qing dynasty was marked by the flourishing of Chinese drawn and printed popular prints. The export of such a bright and exotic type of painting was carried out both to Western Europe and Russia; of course, it reached Korea in large quantities. The Chinese popular print, filled with benevolent symbols, influenced Korean engraving and, in many ways, gave impetus to the development of the bright minhwa folk painting in the late Chosŏn period. It later began to develop according to its own laws and canons, in accordance with the requests of a new customer, a native of the lower and middle classes.

Basically, the minhwa folk painting in the birdand-flower genre was performed in the format of large eight-winged and small double-winged screens. There was a real demand for such bright colour hwajodo paintings in the art market.

Hwajohwa of the End of the Chosonn Period (c. 1800-1910)

The hwajohwa painting of the end of the Chosŏn period continued the tradition established by Kim

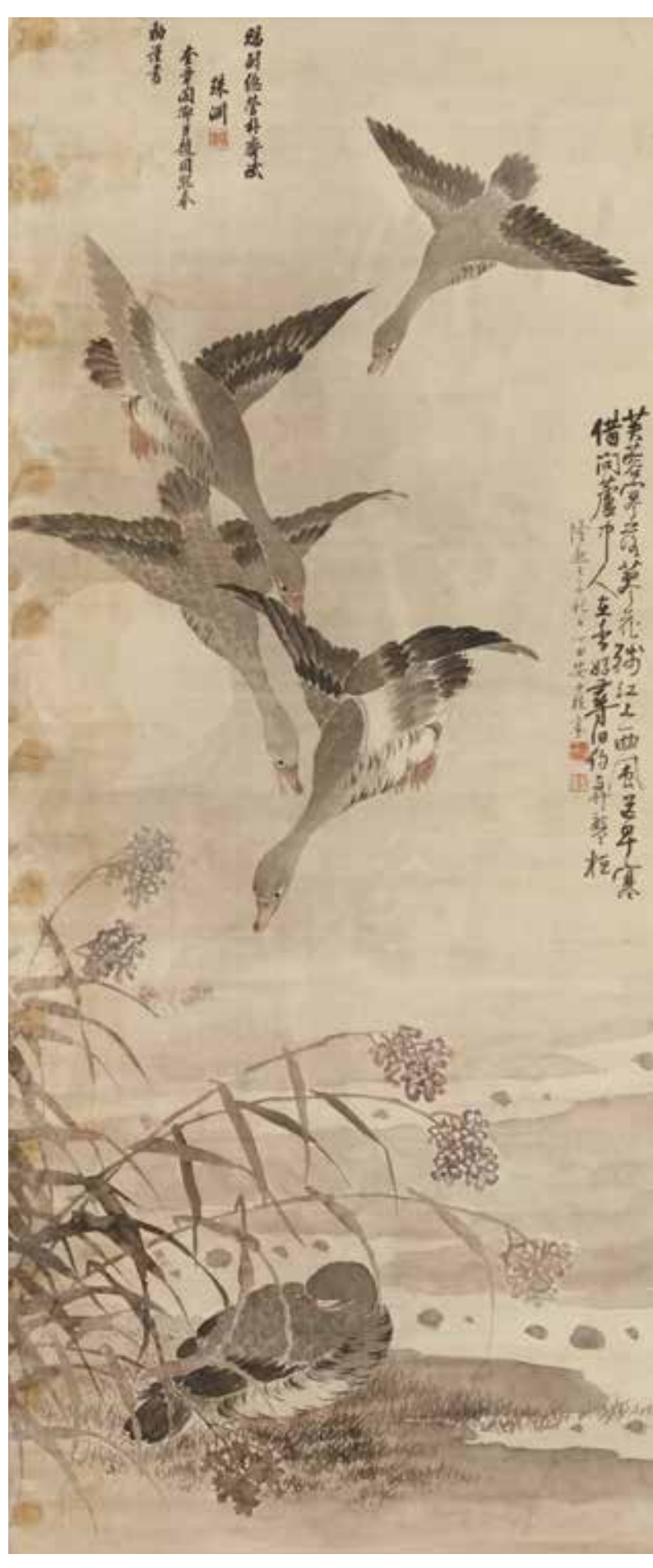

(Fig. 9) An Junsik, Wild Geese in the Reed, silk, ink,
watercolours, tamch'ae technigue, $2438 \times 82$ cm,

watercolours, tamch'ae technique, $243.8 \times 82 \mathrm{~cm}$, 1909, National

Hondo; however, it also reflected a new approach to conveying the artist's personal feelings. This expressive approach was used mainly to depict landscapes and bird-and-flower paintings, assuming a lapidary brushwork and giving fresh aesthetic sensations and experiences.

In hwajohwa new trends mixed with the traditional saŭich'e (사의체 寫意體), "painting of ideas", characteristic of the middle Chosŏn period [1, pp.75-76]. 
A screen displaying birds by Hong Sesŏp (홍세섭 洪 世縞, pseudonym: Sŏkch'ang 석창 石空, 1832-1884) from the National Museum of Korea is a prime example. Today, the folds of this screen are divided into eight separate scrolls. Hong Sesǒp's pictorial method demonstrates a connection with the work of Zhū Dā (朱目, 1626-1705), one of the prominent artists of the Qing Dynasty. At the same time, Hong Sesŏp's technique of using light and dark ink is reminiscent of Western watercolour painting. In his works, he used the effect of "smeared ink", the specific organisation of the composition in the image of flying wild ducks, as well as a bold perspective from a bird's eye view. The later technique was used in the painting Swimming Ducks [in a Stream of Water] (유압도 游鴨圖) (Fig. 7). However, Hong Sesǒp's main artistic approaches corresponded to the past traditions introduced by Cho Sok [3, p.60].

The last years of the Yi dynasty were a difficult moment in Korean history, associated with the gradua opening of the country to the outside world. At this time, the hwajohwa genre acquired a new free style under the influence of the painting of artist Chang Sŭngŏp (장승업 張承業, pseudonym: Owŏn 오원 픔 園, 1843-1897). However, it is believed that this style was not so sublime and elitist. A native of the common people, Chang Sŭngŏp did not have a systematic artistic education; his work developed under the influence of Shanghai masters' painting, which appeared in Korea in the second half of the $19^{\text {th }}$ century $[3, \mathrm{p} .61]$. However, the artist had distinctive talent and eventually became very popular among wealthy customers and was even able to organise his own workshop in the centre of Seoul. Chang Sŭngŏp brought into fashion the image of birds of prey sitting on one leg on a tree branch. The paintings Fearless Eagles (호취도 ㅁㅜㅜㄹ⿺ (Fig. 8) and A Pair of Pheasants (쌍치도 雙雉圖) from the Leeum Museum show the living style of Chang Sŭngŏp. The artist used molgolpŏp, the "boneless" technique (몰골법 沒骨法), that is the method of depicting an object using ink or paints without drawing a contour, the effect of "smeared ink", as well as light colouring [4, pp.372-374]. The artist's works are characterised by an improvised and lively character.

The artist also popularised the noando art form (노안도 藘雁圖, literally: "wild geese in the reed"). The master painted wild geese in flight, descending to the reed field. A vertical silk scroll of this type by Chang Sunngŏp is kept at the Institute of Oriental Manuscripts of the Russian Academy of Scienc- es in St. Petersburg and was described by L.Kireeva [2, pp.32-35]. It was named Wild Geese.

Chang Sŭngŏp's artistic approaches to the $h w a-$ johwa genre were continued and developed by Cho Sŏkchin (조석진 趙錫晉, pseudonym: Sorim 소림 小琳, 1853-1920) and An Junsik (안중식 安 中植, pseudonym: Simjŏn 심전 心田, 1861-1919) already at the end of the Chosŏn era. Wild Geese in the Reed (노안도 蘆雁圖), a scroll by An Jun sik from the National Museum of Korea (Fig 9), is an excellent example of this continuity. Reed and wild geese motifs in screens, scrolls and fan became the mainstay of Korean flower and bird painting until the 1920s, when they were replaced by a completely new style of contemporary Japanese art.

Summing up, we emphasise once again that the hwajohwa genre had been prevalent in Kore for many centuries. Artists of various schools and philosophies turned to it; images of flowers and birds adorned palaces and ordinary houses, combined benevolent symbols, and embodied the highest harmony of nature. To comprehend the essence of the depicted objects, Korean masters sought to merge with the life of plants and birds. To dissolve in it, they intently and thoughtfully peered into the details and subtle nuances of wildlife, transferring them to paper and silk.

Great social changes in Korea in the $18^{\text {th }}$ cen tury, accompanied by an active search for nation self-identification, brought to the stage a new customer who came from the middle strata of Korean society. Their tastes, along with the tastes of representatives of the ruling elites, began to shape the artistic culture of their time. The influence of traditional Chinese painting and the gradual penetration of Western European creative techniques into the Korean Peninsula was reflected in Korean traditional painting, including in the bird-and-flower genre gradually bringing the Korean culture to those profound changes that took place in it at the beginning of the $20^{\text {th }}$ century, when Korea became a colony of Japan and started to be involved in the sphere of the global influence of world culture

REFERENCES

1. Vostrikova, E.A. 2021. "The Hwajohwa Genre (Bird-andflower Painting) in Korean Traditional Painting of the Early and Middle Chosŏn Periods (Late 14th - Late 17 Centuries)", Art Literature Scientific and Analytic Journal Burganov House. The Space of Culture, vol. 17, no. 2 pp. 61-78. DOI: 10.36340/2071-6818-2021-17-2-61-78

2. Kireeva, L.I. 2006. "Chang Sŭngōp's Scroll in the LO INA Collection", Articles on Korean Art: a Collection of Selected Articles and Notes. Magnitogorsk: MAGU, pp. 32-35.

3. Hong Sunpyo. 2008. "Hwajohwa of the Goryeo and Chosonn Dynasties", The International Journal of Korean Art and Archaeology, Seoul: National Museum of Korea, vol. 02, pp. 43-65.

4. Park Youngdae. 2004. Essential Korean Art from Prehistory to the Chosonn Period. Seoul: Heonamsa Publishing Co., p. 420.

5. 澗松文華. - 서울: 한국민족미술연구소, 2009. № 76. - 246 쪽. (Kansong Munhwa. Seoul: Hanguk Minjok Misul Yonguso, 2009. Vol. 76. p. 246)

6. 강명석, 리경수. 우리 민족의 옛 미술가들. - 평양: 평양 출판사, 2009. - 303쪽. (Kang Myŏngsǒk, Y Gyŏngsu. Old Painters of Korea. Pyongyang: Pyongyang Ch'ulp'ansa, 2009. p. 303)

7. 백인산. 우리 문화와 역사를 담은 엣 그림의 아름다움. 간송미술36_회화. - 서울: 컬처그라퍼, 2016. - 307쪽 (Paek Insan. The Beauty of Ancient Paintings that Tell us About Korean Culture and History. 36 Masterpieces of the Kansong Art Museum. Seoul: Kholch'okŭrap'o 2016. p. 307)

8. 화훼영모 - 자연을 품다. - 서울: 간송미술문화재단 2015. - 221 쪽. ("Flowers, Birds and Animals: a Reflection of Nature". Exhibition Album. Seoul: Kansong M sul Munhwachaedan, 2015. p. 221)

: 솔, 2008. - 498 쪽. (O Jusŏk. Tanwŏn Kim Hondo. Seoul: Sol, 2008. p. 498)

LIST OF ELECTRONIC RESOURCES:

The Royal Mauritshuis Gallery official website: https:// www.mauritshuis.nl

The Leeum Museum (Leeum 미술관) official website: http://www.leeum.org/html/global/main.asp

The National Museum of Korea (국립중앙 박물관) of ficial website: https://www.museum.go.kr/site/main/ home

The Seongmun University Museum (선문대학교 박물관) official website : $\mathrm{htt} p: / /$ museum.sunmoon.ac.kr The Rijksmuseum official webs: https://www.rijksmuseum.nl

Kansong Art Museum (간송미술관) official website: http://kansong.org 
Екатерина Александровна Вострикова Московского государственного университета имени М.В. Ломоносова, соискатель Кафедры истории искусств и гуманитарных наук Московской государственной художественно-промышленной академии имени С.Г. Строганов e-mail: dolihotella@ hotmail.com Москва, Россия

ORCID 0000-0002-2093-595X

DOI: 10.36340/2071-6818-2021-17-3-31-49

\section{ЖАНР ХВАДЖОХВА («ЦВЕТЫ И ПТИЦЫ») В КОРЕЙСКОЙ ТРАДИЦИОННОЙ ЖИВОПИСИ ПОЗДНЕГО ПЕРИОДА ЧОСОН (XVIII - НАЧАЛО ХХ ВВ.)}

Аннотация: Настоящая статья посвящена художественному жанру хваджохва («цветы и птицы») позднего периода Чосон (XVIII - начало XX вв). В исследовании обозначен историко-культурный контекст, прослежена стилевая эволюция жанра «цветь и птицы». Отмечены национальные особенности присущие корейской живописи хваджохва, а также влияние традиционных китайских стилей и западноевропейских живописных техник на жанр «цветы и птицы». Автор очерчивает круг ведущих художников, работавших в данном жанре.

B XVIII в. направление «цветы и птицы» в Корее претерпело значительную трансформацию. Творчество профессиональных художников Чон Сона и Пён Санбёка демонстрирует новый реалистический поход к живописи хваждохва. Художники стали тщательно наблюдать за структурными характеристиками изображаемых объектов живой природы. Признанным мастером жанра «цветы и птицы» также являлся художник Сим Саджон, его творчество базировалось на живописных принци пах и эстетике китайской «южной школы», влияние которой было очень сильно в Корее.

Ведущий художник позднего периода Чосон Ким Хондо для своих произведений с цветами и птицами в качестве фона активно использовал традиционный пейзаж, однако в изображении живых существ ушёл от формальных шаблонов, вписывая птиц в реалистические сцены природы. Ким Хондо
Эпоха Чосон (правление династии Ли 13921910 гг.) - это промежуток корейской исто рии протяжённостью в пятьсот лет. Настоящая статья является продолжением исследования [1, с. 72-78] жанра «цветы и птицы» в корейской традиционной живописи и описывает процессы, происходившие в обозначенном художественном направлении в Kopeе в XVIII - начале XX в. В современном южнокорейском искусствознании этот промежуток истории принято называть поздним периодом Чосон и подразделять на два этапа: собственно, поздний период Чосон, условно датируемый 1700-1800 гг., и конец эпохи Чосон - условно 1800-1910 гг. (обратим внимание, что некоторые корейские исследователи датируют конец периода Чосон с 1850 до 1910 г.). Автор использует термины хваджохва (화조화 花 鳥畫) для обозначения жанра «цветы и птицы» и хваджодо (화조도 花鳥圖), обозначающий картины, выполненные в данном жанре [подробнее

о терминологических особенностях см. 1, с. 73].

Хваджохва в поздний период Чосон

\section{(ок. 1700-1800 rr.)}

XVIII век в истории периода Чосон считается одним из самых стабильных и благополучных: на Корейском полуострове не происходило войн или иноземных вторжений, активно развивались торговля и промыслы, средний класс мелких чиновников, торговцев и ремесленников постепенно богател. С приходом к власти Маньчжурской династии в Китае (1644-1912 гг.), которую корейцы считали «варварской», Чосон в глазах собственной интеллигенции стал восприниматься как новый центр/сердце неоконфуцианской культуры. Несмотря на продолжающееся влияние Китая в корейских образованных кругах начинаются поиски самоидентификации, сопровождавшиеся ростом национального самосознания, что нашло прямое отражение в искусстве и живописи

В первую очередь эти тенденции проявились в заметном развитии направлений пейзажа «подлинного вида» чингён сансухва (진경산수화 厝 景山水畫) и бытовой жанровой живописи пхунсокхва (풍속화 風俗畫). Однако и жанр хваджохва претерпел значительную трансформацию. Данный процесс был связан с появлением новых художественных течений и укреплением в Корее влияния китайской «южной школы», или живописи намджонхва (남종화 南宗畫, кит. наньизухуа)

Монохромная живопись тушью, тяготевшая к каллиграфичности и условности, малопонят- ная в народной среде, пошла на спад. Писание же тушью и водяными красками чхэмукпхун (채묵풍 彩墨風), детальность проработки карначале правления династии Ли (1392-1550 гг) [1, с. 74-75], опять получили широкое распро странение. В средних слоях корейского общества, благосостояние которых значительно укрепилос к XVIII в., возрос спрос на живое яркое изображение природы. Более того, завезённые из раннецинского Китая изобразительные альбомы для копирования теперь состояли из цветных ксилографий, что также сказывалось на формировании вкусов и эстетических потребностей корейского общества.

Одно из ключевых мест в формировании национальной живописи Кореи занимает художник Чон Сон (정선 鄭整, псевд. Кёмджэ 겸 재 啸 齋, 1676-1759 гг.), прославившийся в первую очередь своими пейзажами «подлинного вида». Он мало писал в жанре «цветы и птицы», но корейские искусствоведы в один голос заявляют, что Чон Сон обладал непревзойдённым талантом в передаче сути природы и живых существ. До нас дошли его произведения «Физалис и петух» (등롱웅 계도 燈籠雄䊿瞗) (рис. 1) и «Целозия и поздние [осенние?] цыплята» (계관만추도 鶏冠晚雏圖) из Художественного музея Кансон. В картинах компо зиция традиционна, мы видим сосредоточение основных объектов в одном углу небольшого пейзажа, однако изображение птиц и растений демонстрирует реалистический подход в живописи [5, с. 234-235]. В «Физалисе и петухе» перекличка оранжевого и красного в плодах растения $и$ оперении птицы привлекает внимание зрителя, мастер с большим увлечением работает с ярким цветом, нанося несколько слоёв краски чтобы добиться максимальной интенсивности тона.

Такой реалистический подход базировался на чадыкчок (자득적 自得的), т.е. самообучении путём наблюдения за структурными характеристи ками и мельчайшими особенностями изучаемого объекта. Данное направление в живописи развивал художник Чо Ёнсок (조영석 趙榮祏, псевд Кванаджэ, Соккесаин 관아재 觀我齋, 석계산인 不 溪山人, 1686-1761 гг.), который писал предме именно таким, каков он есть, или чынмуль сад жин (즉물사진 師物寫道). Он был другом детства и соседом великого Чон Сона. На первом этап работы Чо Ёнсок практиковал грубые зарисовки ивовым углем ютхан якса (유탄약사 柳炭略寫) 
Создавая свою известную картину «Сороки на сосне»/《Пара сорок» (송작도 松鵲圖/쌍작도 雙 鹊圖) из частного собрания, Чо Ёнсок работал тушью и белилами хобун (호분 胡粉), базируясь как раз на таких натурных эскизах. Принципи альное отличие данного произведения от картин среднего периода Чосон (ок. 1550-1700 гг.) в изменившейся иконографии: вместо прихотливо изогнутых, как бы изломанных тонких веточек сливы или бамбука, на картине мощная ветвь сосны, служащая надёжной опорой лёгким, будто невесомым птицам.

Яркими многоцветными произведениями в жанре «цветы и птицы» прославился выдающийся придворный художник Пён Санбёк (변상벽 相璧, псевд. Хваджэ 화재 和齋, 1730-1775? гг.) Мастер получил прозвища «Пён-кот» за вели колепные рисунки кошек и «Пён-петух» за изображение петухов и куриц. Его картина «Петух и курицы охраняют цыплят» (자웅장추도 雌雄將雛圖) из Художественного музея Кансон (рис. 2) считается одной из вершин жанра хваджохва в корейской традиционной живописи [7, с. 128-135; 8 c. 109]. Работа характеризуется нетипичной реалистичностью исполнения. Прекрасно передан контраст между оперением взрослых птиц и лёгким пушком, покрывающим цыплят. Жёсткие перья петуха как бы бликуют, отражая солнечный свет, цыплята же кажутся почти бестелесными.

Картине присуща новаторская композиция: птицы представлены в смелых ракурсах и поворотах, подчёркивающих пространственную глубину. Такие приёмы явно были заимствованы из арсенала западноевропейского искусства.

Стоит отметить, что в XVIII в. на Корейский полуостров через цинский Китай хоть и опосредованно, но начинают просачиваться западные живописные приёмы. При дворе императоров Канси (1661-1722 гг.) и Цяньлуна (1735-1796 гг.), которые считаются величайшими покровителями искусства, работали иностранные художники, самым известным из которых был монах-иезуи Джузеппе Кастильоне (1688-1768 гг.). В придворной академической живописи китайские художники стали применять линейную и воздушную перспективы, использовать светотень. Корейцы, в составе дипломатических миссий регулярно посещавшие Пекин, безусловно имели возможность познакомиться с новыми культурными веяниями принесёнными в Китай многочисленными хри стианскими миссионерами и торговыми компа- ниями. Постепенно корейские художники тоже начали применять методы и техники европейского изобразительного искусства.

В XVII-XVIII вв. в западноевропейском искусстве становится популярным изображени птичьих дворов (рис. 3), птичьих концертов, ку рятников, петушиных боёв. Одними из ведущих мастеров этого анималистического направления стали голландские художники Гейсберт Гиллис де Хондекутер (1604-1653 гг.) и его сын Мельхиор де Хондекутер (1636-1695 гг.), последний даже получил у современников прозвище «Птичий Рафаэль». В этот период в Китай ввозилось большое количество предметов западноевропейского ис кусства, и мы не можем исключать, что картин с сюжетами, подобными сюжетам Хондекутеров, попадали на дальневосточный рынок.

Безусловно, нет никаких неопровержимых доказательств прямого заимствования Пён Санбёком сюжета картины «Петух и курицы охраняют цыплят», но вероятность опосредованного влияния очень велика. Круговая композиция расположения фигурок птиц, охраняющих своих птенцов, размещение их тел в пространстве, подчёркну тая реалистичность изображения - всё для корейской живописи ново.

Также в поздний период Чосон в жанре «цве ты и птицы» было популярно направление, ис пользовавшее технику сумук тамчхэпхун (수묵담 채풍 水墨淡彩風, писание тушью с лёгким окра( ровалось на живописных принципах и эстетике китайской «южной школы». Признанным мастером этого направления являлся Сим Саджон (심사 정 沈師正, псевд. Хёнджэ 현재 玄齎, 1707-1769 гг. художник непростой творческой и человеческой судьбы, проживший скромную уединённую жизн и умерший в бедности. Однако он внёс большой вклад в развитие корейской традиционной жи вописи и был известным мастером в рисовании цветов, птиц и насекомых.

Повторяя живописный стиль цинского художника Цзян Тинси (蔣廷錫, 1669-1732 гг.), Сим Саджон иногда использовал яркую технику «тщательной кисти» конпхиль чхэсэкпхун (공필채색풍 工筆彩色風), т.е. аккуратное и точное контурное изображение объектов с большим вниманием к деталям и формам [3, с. 57]. Такую живописную манеру художника прекрасно демонстри рует картина «Утки на лотосовом пруду» (연지 유압도 蓮池遊鴨圖) из Музея Лиум. Но в то же время Сим Саджон применял в своём творчестве самые разные художественные техники. Частично он продолжал традицию Чо Сока (조속 埳 涑, псевд. Чханган 창강 滄汇, 1595-1668 гг.), художника-интеллектуала среднего периода Чосон $[1$, c. 76], что можно увидеть в свободной и мощной работе кистью в картине «Птичка [зимородок] чувствует аромат» (수금문향 水禽聞香) из музея Кансон (рис. 4). Сим Саджон предпочитал изображать ястребов, фазанов, дятлов и зимородков. Художник был великолепным колористом, его живопись узнаваема и выделяется среди работ современников.

Творчеством Сим Саджона восхищались представители ёхан (여항 䦓巷, низшее образованное социальное сословие, сформировавшееся в поздний период Чосон из мелких чиновников), например, художники Чхве Бук (최북 崔北, псевд Хосэнгван, Самгиджэ 호생관 毫生館, 삼기재 三奇 齋, 1712-1786 гг.), который великолепно писал охотящихся орлов, и Ким Хондо (김홍도 金弘道, псевд. Танвон, Тангу, Сохо 단원 檀園, 단구 丹邱, 서호 西湖, 1745-1806 гг.).

Ким Хондо - поистине значимая фигура в культурной жизни Кореи, он был одним из лучших придворных художников вана Чонджо (정조 표 祖, 1776-1800 гг.), обладал большим талантом, его творческий диапазон весьма широк [9]. На формирование художественного мира Ким Хондо оказали большое влияние произведения Чон Сона и Сим Саджона.

Художник оставил после себя много картин с дикими утками, цаплями, сороками, фазанами, ястребами и журавлями. Для своих хваджодо Ким Хондо как фон использовал традиционные малый и большой пейзаж, однако в изображении живых существ смог уйти от типичных и формальных шаблонов, вписывая птиц в реалистические сцены природы с горами, долинами, сельскими полями. Он активно использовал многофигурные композиции с характерной жанровой повествовательностью, занимательностью сюжета. Лучшие картины художника с птицами - это «Утки, плывущие по реке» (계류유압도 溪流游鴨圖), «Пара фазанов в осеннем лесу» (추림쌍치도 秋林雙雉圖) (рис. 5) и «Радостно стрекочущие сороки весной» (춘작보희도 春鵲報喜圖), все они входят в «Живописный альбом года пёнджин» (병진년화칩 丙辰年畫帖) из музея Лиум. Мастерская работа ярким чистым цветом, выверенная компози - ция, сбалансированная пустым пространством, отличают стиль Ким Хондо.

В поздний период Чосон в большом количестве стали писаться картины, выполненные в сине-зелёном колорите стиля чхоннокпхун (청록풍 靑綠風), где использовался яркий насыщенный цвет в изображении птиц, цветущих деревьев, камней и скал. Повышенные условность и декоративность картин данного стиля сделали их одними из самых популярных предметов убранств не только во дворцах, но и в домах представи телей среднего класса чунъинов (중인 中人), 6о гатых торговцев и купцов.

Среди декоративных цветных хваджохва были популярны яркие по цветовому решению ширмы с соснами и журавлями сонхакто (송학도 松鹤 圖) и хэхакпандорю (해학반도류 海鶴蟠桃類), изображения, сочетающие журавлей и персиковые деревья как символы долголетия и бессмертия. Такими ширмами часто украшали дворцы, они демонстрировали богатство обладателя и тонкую работу художника (рис. 6)

«Цветы и птицы» (화조도 花鳥圖) Син Ханпхён (신한평 申漢枰, псевд. Ильджэ 일 재 逸齋, 1726-? гг.) из музея Лиум, «Разноцветные птицы среди цветущих деревьев» (화림채금도 花林彩禽圖) Ли Ыйяна (이의양 李義養, псевд. Синвон 신원 信園, 1768-? после 1824 гг.) из музея Кансон и упомянутые выше ширмы объединяет яркое цветовое соче тание зелёного и красного, тонкими линиями на всех этих произведениях изображены необыкновенно красивые стилизованные птицы и растения.

Популярность жанра хваджохва в XVIII в. во многом связана с экономическим ростом и улуч шением благосостояния рядовых обывателей. Для всех слоёв населения писались картины, приуроченные к религиозным и шаманским ритуалам различным праздникам, с пожеланиями долголетия и счастливого Нового года, но очень много произведений в жанре «цветы и птицы» предназначалось просто для украшения дома, превращения его в фантастический райский уголок [3, с. 59]. Интересно, что в поздний период Чосон бо́льшая часть картин с цветами и птицами создавалась художниками из народа, это были образцы народной живописи минхва (민화 民畫) Связано это частично с тем, что период правления династии Цин отмечен расцветом китайского рисованного и печатного лубка. Экспор такого яркого и экзотичного вида живописи осу ществлялся и в Западную Европу, и в Россию, ко- 
нечно же, он в большом количестве доходил и до Кореи. Китайский лубок, наполненный благопожелательной символикой, влиял на корейскую гравюру и во многом дал толчок развитию в поздний период Чосон яркой народной живописи минхва, которая позже стала развиваться уже по своим законам и канонам, в соответствии с запросами нового заказчика, выходца из низших и средних сословий.

В основном народная живопись минхва в жанре «цветы и птицы» выполнялась в формате больших восьмистворчатых и маленьких двух створчатых ширм. На рынке искусства наблюдался настоящий бум заказов на такие картины хваджодо, выполненные в ярком цвете.

Хваджохва конца периода Чосон (ок. 1800-

\section{$1910 \mathrm{rr}$.)}

Живопись хваджохва конца периода Чосон продолжала традиции, заложенные Ким Хондо, но также в ней отразился новый подход к передаче личных ощущений художника. Этот экспрессивный подход использовался в основном в изображении пейзажей и «цветов и птиц», предполагая лапидарную работу кистью и давая свежие эстетические ощущения и переживания.

В хваджохва новые веяния смешались с традиционной «живописью идей» саыйчхе (사의체 寫 意體), характерной для среднего периода Чосон [1, с. 75-76]. Ярким примером является ширма с изображениями птиц Хон Сесопа (홍세섭 洪世䛓, псевд. Сокчхан 석창 石空, 1832-1884 гг.) из Национального музея Кореи Створки этой ширмы сегодня разделены на восемь отдельных свитков. Живописный метод Хон Сесопа демонстрирует связь с творчеством Чжу Да (朱脊, 1626-1705 гг.) одного из выдающихся художников династии Цин. При этом техника использования светлой и тёмной туши у Хон Сесопа напоминает западную акварельную живопись. В своих работах он применяет эффект «смазанной туши», специфическую организацию композиции в изображении летящих диких уток, а также смелый ракурс с высоты птичьего полёта. Последний приём использован в картине «Плывущие утки [в водном потоке]» (유압도 游鴨圖) (рис. 7). Однако основные художественные подходы Хон Сесопа соответствовали прошлым традициям, внедрённым ещё Чо Соком [3, с. 60].

Последние годы правления династии Ли - непростой момент корейской истории, связанный с постепенным открытием страны для внешнего мира. Жанр хваджохва в это время обрёл новый свободный стиль под влиянием живописи художника Чан Сынъопа (장승업 張承業, псевд. Овон 오 원 吾園, 1843-1897 гг.). Тем не менее считается, что данный стиль был не такой возвышенный элитарный. Выходец и простонародья, Чан Сынъоп не имел системного художественного образования, его творчество развивалось под влиянием живописи шанхайских мастеров, хлынувшей во второй половине XIX в. в Корею [3, с. 61], однако художник обладал самобытным талантом со временем стал очень популярен среди богатых заказчиков и смог даже организовать свою мастерскую в центре Сеула. Чан Сынъоп ввёл моду изображение хищных птиц, сидящих на одной ноге на ветви дерева. Картины «Бесстрашные орлы» (호취도 豪熟圖) (рис. 8) и «Пара фазанов (쌍치도 雙雉圖) из Музея Лиум демонстрируют живой стиль Чан Сынъопа, автор применяе «бескостную» технику мольгольпоп (몰골법 沒骨 法), т.е. метод изображения объекта с помощью туши или красок без прорисовки контура, эффект «смазанной туши», а также лёгкое окрашивание [4, c. 372-374]. Работам художника присущ импровизированный и живой характер.

Также художник популяризировал художественную форму ноандо (노안도 蘆雁圖, дословно «дикие гуси в тростнике»). Мастер писал диких гусей в полёте, спускающихся к полю тростни ка. Вертикальный шёлковый свиток Чан Сынъопа данного типа хранится в Институте восточных рукописей РАН в Санкт-Петербурге и был описан Л.И. Киреевой [2, с. 32-35], он получил название «Дикие гуси».

Художественные подходы Чан Сынъопа в жанре хваджохва были продолжены и развиты Чо Сокчином (조석진 趙錫晉, псевд. Сорим 소림 小 琳, 1853-1920 гг.) и Ан Джунсиком (안중식 安中 植, псевд. Симджон 심전 心田, 1861-1919 гг.) уже на излёте эпохи Чосон. Прекрасным примером такой преемственности является свиток «Дикие гуси в тростнике» (노안도 蘆雁圖) Ан Джунсика из Национального музея Кореи (рис. 9). Мотивы с тростником и дикими гусями, реализованные ширмах, свитках и на веерах, стали основными в корейской живописи жанра «цветы и птицы» вплоть до 1920-х годов, когда им на смену пришёл совершенно новый стиль сов кого искусства.

Подводя итоги, ещё раз подчеркнём, что жанр хваджохва на протяжении многих веков был очен популярен в Kорее, к нему обращались художники самых разных школ и философских воззрений изображения цветов и птиц украшали дворцы и обычные дома, сочетали в себе благопожелательные символы и были воплощением высшей гармонии природы. Чтобы постичь суть изображаемых объектов корейские мастера стремились слиться С жизнью растений и птиц, раствориться в ней, они пристально и вдумчиво всматривались в детали и мельчайшие нюансы живой природы, перенося их на бумагу и шёлк.

Глубокие социальные перемены, происходившие в Kорее в XVIII в. и сопровождавшиеся активным поиском национальной самоидентификации вывели на сцену нового заказчика, происходивше-

\section{БИБЛИОГРАФИЯ}

1. Вострикова Е.А. Жанр хваджохва («цветы и птицы») в корейской традичиннй живопичи раннего и ср него период Чосон (конец XIV - конец XVIT  № Дом Бурганова. Пространство культуры, 2021. № 2.- - C. 72 .

2. Киреева Л.И. Свиток Чан Сынопа в собрании ЛО ИНА

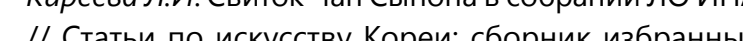
// Статьи по искусству Кореи: сборник избранных статей и

3. Hong Sunpyo. Hwajohwa of the Goryeo and Chosŏn Dynasties // The International Journal of Korean Art and Archaeology. Seoul: National Museum of Korea, and Archaeology. Seoul:

4. Park Youngdae. Essential Korean Art from Prehistory to the Chosŏn Period. Seoul: Heonamsa Publishing Co., the Choson Pe

5. 澗松文華. - 서울: 한국민족미술연구소, 2009. № 76. 246 쪽. (Кансон мунхва. Альбом. Сеул: Хангук минджок мисуль ёнгусо. - 2009. - Т. 76. - 246 с)

6. 강명석, 리경수. 우리 민족의 옛 미술가들. - 평양: 평양 출판사, 2009. - 303쪽. (Кан Мёнсок, Ли Кёнсу. Старые художники Кореи. - Пхеньян: Пхёньян чхульпханса, 2009. $-303 \mathrm{c}$.

7. 백인산. 우리 문화와 역사를 담은 엣 그림의 아름다움. 간송미술36_회화. - 서울: 컬처그라퍼, 2016. - 307쪽. го из средних слоёв корейского общества, его вкусы наравне со вкусами представителей правящих элит стали формировать художественную культуру своего времени. Влияние китайской традиционной живописи и постепенное проникновение на Корейский полуостров западноевропейских художественных техник нашло своё отражение корейской традиционной живописи, в том числе и в жанре «цветы и птицы», постепенно подвояя корейскую культуру к тем глубинным переменам, которые будут происходить в ней уже в начале XX в., когда Корея станет колонией Японии и будет вовлечена в сферу глобального вли яния мировой культуры.
(Пэк Инсан. Красота старинных картин, повествующих нам о корейской культуре и истории. 36 шедевров муsея Кансон. - Сеул: Кхольчхокырапхо, 2016. - 307 с.) 2015 221쪼 연을 품다. - 서울: 간송미술문화재댄 2015. 221․ㄱ. (Цветы, птицы и животные - отражемисуль мунхвачэдан, 2015. - 221 с.). 位, 2008. - 498 쪽.

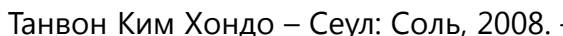
498 c.).

СПИСОК ЭЛЕКТРОННЫХ РЕСУРСОВ

- Официальный сайт Королевской галерея Маури цхёйc https://www.mauritshuis.nl

Официальный сайт Музея Лиум (Leeum 미술관) http://www.leeum.org/html/global/main.asp

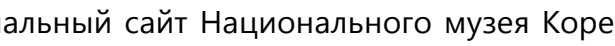
(국립중앙박물관): https://www.museum.go.kr/site/ main/home

Официальный сайт Музея Университета Сонмун (선문대학교 박물관): http://museum.sunmoon.ac.kr Официальный сайт Рейксмюсеума https://www. rijksmuseum.n Официальный сайт Художественного музея Кансон
(간송미술관): http://kansong.org 